\title{
No relationship between the cell surface hydrophobicity of coagulase-negative staphylococci and their ability to adhere onto fluorinated poly(ethylene-propylene)
}

\author{
P. BROKKE, J. DANKERT \\ Department of Medical Microbiology, University of Amsterdam, Meibergdreef 15, $1105 \mathrm{AZ}$, \\ Amsterdam, The Netherlands
}

\author{
A. H. HOGT, J. FEIJEN \\ Department of Chemical Technology, University of Twente, 7500 AE Enschede, The \\ Netherlands
}

The cell surface hydrophobicity of 14 encapsulated and 21 non-encapsulated coagulasenegative staphylococci (CN staph) as determined with the salt aggregation test (SAT) as well as with the xylene-water method ranged widely. Non-encapsulated strains adhered well onto fluorinated poly (ethylene-propylene) (FEP), irrespective of the hydrophobicity of the cell surface. The ability of the encapsulated strains to adhere onto FEP differed also considerably, but no correlation between the number of adherent bacteria and the cell surface hydrophobicity was observed.

\section{Introduction}

Coagulase-negative staphylococci (CN Staph), recognized recently as important pathogens $[1,2]$, are most often involved in infections associated with the use of foreign bodies, such as prosthetic heart valves [3], intravascular catheters [4] or pacemakers [5]. Initial adherence of $\mathrm{CN}$ Staph onto artificial surfaces is thought to be an important step in the development of these infections $[2,6-8]$.

It is unknown which surface structures or surfaces components of $\mathrm{CN}$ Staph mediate adherence onto polymeric surfaces $[9,10]$. Capsules adherent to $\mathrm{CN}$ Staph [11, 12] and extracellular slime $[7,11,13]$ produced by CN Staph may be involved in the adherence process [2]. It has also been suggested that the hydrophobicity of the bacterial cell surface is a relevant property for the adherence of CN Staph to polymeric surfaces $[2,14]$.

Only a small number of studies $[10,15-17]$ have been reported in which a possible correlation between the cell surface hydrophobicity of CN Staph and their ability to adhere onto polymeric surfaces was considered. In one study [15] a correlation between the cell surface hydrophobicity of CN Staph as determined with the xylene-water test and the ability of the bacteria to adhere onto Teflon catheters was found. In a previous study [10] we found that the cell surface hydrophobicity values of $\mathrm{CN}$ Staph as determined by their adherence to xylene did not predict the ability of the test strains to adhere onto fluorinated poly(ethylene-propylene) (FEP), a hydrophobic biomaterial used in many biomedical applications.
Several methods based on different principles have been used to determine the bacterial cell surface hydrophobicity. These methods include the adherence of various bacteria other than $\mathrm{CN}$ Staph to hydrocarbons $[11,18]$, the salt aggregation test (SAT) [19], hydrophobic interaction chromatography [20], and the measurement of the water contact angle on layers of bacteria [21]. In general, no correlation between these various methods [22-24] was obtained.

In this study we compared the cell surface hydrophobicity assessed with the salt aggregation test (SAT) [19] and the xylene-water method [11, 18] of both encapsulated and non-encapsulated CN Staph. In addition, we investigated whether the cell surface hydrophobicity values obtained could be used to predict the ability of CN Staph to adhere onto FEP.

\section{Materials and methods}

\subsection{Bacterial strains and growth conditions}

In total $35 \mathrm{CN}$ Staph strains were used. Seven NCTC strains kindly donated by R. R. Marples (Central Public Health Laboratory, London, UK), were isolated from patients with prosthetic valve endocarditis. Twelve strains designated as S1 through S12 were isolated from at least two sequentially taken blood samples from patients treated in the intensive care unit. The remaining 16 strains $(\mathrm{H} 1$ through $\mathrm{H} 16)$ were derived from the skin flora of open-heart surgery patients.

Twenty-one strains could be identified using the API Staph gallery (API systems S. A. Montalieu, Vercieu, France) as Staphylococus epidermidis, seven 
strains as $S$. saprophyticus, one as $S$. capitis, one as $S$. warneri, two as $S$. heamolyticus, two as $S$. hominis and one as $S$. cohnii.

Fourteen of the 35 strains were encapsulated as demonstrated by the India Ink wet-film method [25].

The strains stored in skim-milk at $-20^{\circ} \mathrm{C}$ and maintained on sheep blood $(5 \% \mathrm{v} / \mathrm{v})$ agar plates (Oxoid Ltd, Basingstoke, Hampshire, UK) at $4{ }^{\circ} \mathrm{C}$, were cultured in Trypticase soy broth (TSB; BBL Microbiology Systems, Cockeysville, MD, USA) for $18 \mathrm{~h}$ at $37^{\circ} \mathrm{C}$ in a rotary shaker incubator (120 r.p.m.; New Brunswick Scientific Co., New Brunswick, NJ, USA). Bacteria were harvested by centrifugation (3000 r.p.m., 10 min; model 3E-1, Sigma, Osterodeam Harz, Germany), washed three times with phosphate buffered saline (PBS; $8.1 \mathrm{~mm} \quad \mathrm{Na}_{2} \mathrm{HPO}_{4}, 1.5 \mathrm{~mm}$ $\mathrm{KH}_{2} \mathrm{PO}_{4}, 140 \mathrm{~mm} \mathrm{NaCl}, 3 \mathrm{~mm} \mathrm{KCl} \mathrm{pH} \mathrm{7.2)} \mathrm{and} \mathrm{sub-}$ sequently resuspended in this buffer.

\subsection{Adherence to xylene and the salt aggregation test}

The adhesion of bacteria to xylene was determined with the xylene-water method as previously reported $[11,18]$ and expressed as the percentage of bacteria adhering to xylene.

In the salt aggregation test (SAT) according to Lindahl et al. [19] the bacterial cells were washed three times with a $20 \mathrm{~mm}$ sodium phosphate buffer (pH 6.8) and resuspended in this buffer to give approximately $5 \times 10^{9} \mathrm{CFU} \mathrm{ml}^{-1}$ as determined by viable count. Concentrations of ammonium sulphate in a $20 \mathrm{~mm}$ sodium phosphate buffer ( $\mathrm{pH} \mathrm{6.8)} \mathrm{ranged} \mathrm{from}$ $0.2 \mathrm{M}$ to $4.0 \mathrm{M}$ with increments of $0.2 \mathrm{M}$. Of these solutions $50 \mu \mathrm{l}$ was added to the wells of a $96 \mathrm{U}$-well microtiter tray (Thovadec, Nieuwkoop, The Nether- lands) containing $50 \mu \mathrm{l}$ of the bacterial suspension. After $12 \mathrm{~h}$ at $4{ }^{\circ} \mathrm{C}$ the SAT value was defined as the lowest final salt concentration inducing bacterial aggregation. Strains aggregating in the phosphate buffer were designated as auto-aggregating.

\subsection{Adherence of CN Staph onto FEP}

Discs (34 mm diameter) of films of FEP (type $500 \mathrm{~A}$; E.I. Du Pont de Nemours \& Co., Inc., Wilmington, DE) were exposed to bacteria $\left(5 \times 10^{8} \mathrm{CFU} \mathrm{ml}^{-1}\right)$ at $37^{\circ} \mathrm{C}$ for $2.5 \mathrm{~h}$ in a rotary shaker incubator at 120 r.p.m. (New Brunswick Scientific Co.) [9, 10]. After rinsing eight times with $3 \mathrm{ml}$ of PBS, adherent bacteria were fixed with $4 \%(\mathrm{v} / \mathrm{v})$ glutaraldehyde in PBS. The number of adhering bacteria was counted using a light microscope by examining six $0.05 \mathrm{~mm}^{2}$ parts on each film. If bacteria adhered to FEP films in clusters, the average number of cells per cluster was counted by high-magnification light microscopy or scanning electron microscopy. All experiments were performed in duplicate. The results were expressed as the number of adherent bacteria per square millimetre of FEP film.

\subsection{Statistical methods}

Correlation coefficients ( $r$ ) of multiple linear regression analyses of data were performed by using standard methods.

\section{Results}

3.1. Cell surface hydrophobicity determined by the SAT and adherence of CN Staph to xylene

Hydrophilic (high SAT value) and hydrophobic (low

TABLE I The cell surface hydrophobicity of non-encapsulated CN Staph as determined with the SAT or with the xylene test and the adherence onto FEP films

\begin{tabular}{|c|c|c|c|}
\hline \multirow[t]{2}{*}{ Staphylococcus strain } & \multirow[t]{2}{*}{ SAT value (M) } & \multicolumn{2}{|c|}{ Adherence to } \\
\hline & & xylene $(\%)$ & $\operatorname{FEP}\left(\right.$ cells $\times 10^{3}$ per $\left.\mathrm{mm}^{2}\right)$ \\
\hline S. epidermidis nctc 100600 & 0.5 & 54 & 74 \\
\hline S. epidermidis nctc 100623 & 1.7 & 12 & 70 \\
\hline S. epidermidis nctc 100641 & 0.5 & 42 & 43 \\
\hline S. epidermidis netc 100893 & 0.6 & 57 & 71 \\
\hline S. epidermidis nctc 100894 & 0.6 & 79 & 69 \\
\hline S. epidermidis nctc 100835 & 1.7 & 7 & 56 \\
\hline S. epidermidis K $2(\mathrm{H} 1)$ & 0.3 & 21 & 60 \\
\hline S. epidermidis $\mathrm{G} 1(\mathrm{H} 2)$ & 0.7 & 52 & 63 \\
\hline S. epidermidis $\mathrm{G} 2(\mathrm{H} 3)$ & 1.2 & 75 & 63 \\
\hline S. epidermidis H $1(\mathrm{H} 4)$ & 0.7 & 76 & 81 \\
\hline S. epidermidis I $41(\mathrm{H} 5)$ & 0.6 & 77 & 85 \\
\hline S. epidermidis pre 69 (H6) & 0.5 & 83 & 67 \\
\hline S. epidermidis I $1(\mathrm{H} 7)$ & 1.4 & 85 & 59 \\
\hline S. epidermidis IV 6 (H8) & 0.7 & 89 & 59 \\
\hline S. epidermidis I $36(\mathrm{H} 9)$ & 0.7 & 95 & 54 \\
\hline S. epidermidis SL 76 (S1) & 0.2 & 44 & 64 \\
\hline S. epidermidis SL 58 (S2) & 0.2 & 83 & 70 \\
\hline S. epidermidis sep 2 (S3) & 0.8 & 86 & 61 \\
\hline S. epidermidis SL 26 (S4) & 0.9 & 90 & 79 \\
\hline S. epidermidis sep 1 (S5) & $0^{\mathrm{a}}$ & 80 & 75 \\
\hline S. saprophyticus pre $40(\mathrm{H} 10)$ & 1.6 & 52 & 87 \\
\hline
\end{tabular}

${ }^{a}$ Auto-aggregating strain. 
TABLE II The cell surface hydrophobicityof encapsulated CN Steph as determined with SAT or with the xylene test and the adherence onto FEP films

\begin{tabular}{llll}
\hline Staphylococcus strain & SAT value (M) & Adherence to & \\
\cline { 3 - 4 } & & xylene (\%) & FEP $\left(\right.$ cells $\left.\times 10^{3} \mathrm{per} \mathrm{m}^{2}\right)$ \\
\hline S. epidermidis nctc 100892 & 0.1 & 72 & 65 \\
S. saprophyticus SAP 1 (H11) & 2.0 & 6 & 15 \\
S. saprophyticus A 1 (H12) & 1.3 & 93 & 33 \\
S. saprophyticus GB 171 (S6) & $0^{\mathrm{a}}$ & 89 & 71 \\
S. saprophyticus GB 103 (S7) & $0^{\mathrm{a}}$ & 86 & 84 \\
S. saprophyticus GB 149 (S8) & $0^{\mathbf{a}}$ & 87 & 31 \\
S. saprophyticus GB 51 (S9) & 0.5 & 75 & 29 \\
S. capitis GB 325 (S10) & 1.2 & 68 & 22 \\
S. warneri PRE 12 (H13) & 1.8 & 46 & 41 \\
S. heamolyticus GB 52 (S11) & 2.0 & 46 & 25 \\
S. heamolyticus A 2 (H14) & 0.1 & 92 & 54 \\
S. hominis Y 2 (H15) & 0.3 & 93 & 42 \\
S. hominis SL 33 (S12) & 1.5 & 89 & \\
S. cohnii K 1 (H16) & 0.5 & 91 & \\
\hline
\end{tabular}

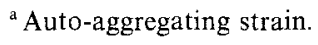
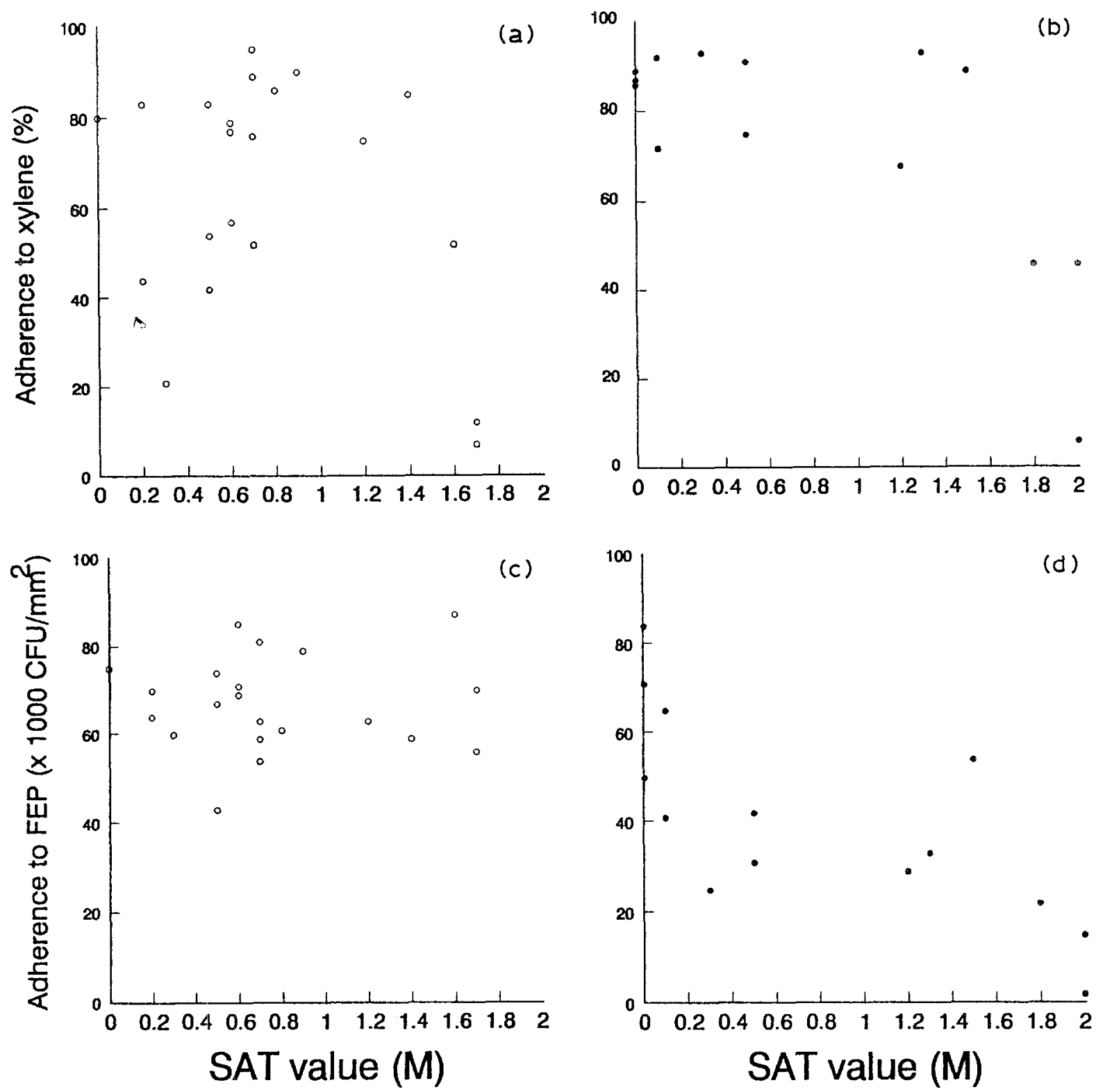

Figure 1 (a) Adherence of 21 non-encapsulated and (b) 14 encapsulated CN Staph strains to xylene as a function of the lowest final concentration of ammonium sulphate (SAT value) inducing bacterial aggregation. Correlation coefficients were -0.33 and -0.71 , respectively. (c) Adherence of 21 non-encapsulated and (d) 14 encapsulated CN Staph strains onto FEP films as a function of the lowest final concentration of ammonium sulphate (SAT value) inducing bacterial aggregation. Correlation coefficients were -0.02 and -0.72 , respectively. The standard deviation of the measurements in the SAT and xylene-water method was approximately $\pm 10 \%$. 
SAT value) strains were present among the nonencapsulated (Table I) as well as among the encapsulated strains (Table II). One non-encapsulated strain and three encapsulated strains showed auto-aggregation in the test buffer.

The ability of non-encapsulated (Table I) and encapsulated strains (Table II) to adhere to xylene ranged widely.

\subsection{Adherence of CN Staph onto FEP}

Non-encapsulated CN Staph strains adhered in higher numbers onto FEP than encapsulated strains. The mean numbers of non-encapsulated bacteria adhering onto FEP ranged from $43 \times 10^{3}$ to $87 \times 10^{3} \mathrm{CFU}$ per $\mathrm{mm}^{2}$ of FEP (Table I), mean numbers of encapsulated bacteria adhering onto FEP ranged from $1.6 \times 10^{3}$ to $84 \times 10^{3} \mathrm{CFU}$ per $\mathrm{mm}^{2}$ of FEP (Table II). The extent of the number of adhering bacteria of strains derived from blood cultures of patients with endocarditis, and of patients with septicemia, or from the skin was not different.

\subsection{Correlation between the SAT value and the adherence to xylene}

Comparing the SAT value and the adherence to xylene the distribution of non-encapsulated strains (Fig. 1a) and of encapsulated strains (Fig. 1b) was similar, except for six of the non-encapsulated strains. Although both non-encapsulated and encapsulated strains with SAT values higher than 1.4 showed a low adherence to xylene, no correlation $(r=-0.33)$ between the adherence to xylene and the SAT value was found. A weak correlation $(r=-0.71)$ was found between the adherence to xylene and the SAT value for the encapsulated strains (Fig. 1b).

\subsection{Correlation between the SAT value and the adherence onto FEP}

No correlation $(r=0.02)$ between the SAT value and the ability of the non-encapsulated CN Staph strains to adhere onto FEP was found (Fig. 1c). Four encapsulated strains with a low SAT value showed a rather high adherence onto FEP. However, there was a poor correlation $(r=0.72)$ between the adherence of encapsulated $\mathrm{CN}$ Staph strains onto FEP and their SAT value (Fig. 1d).

\section{Discussion}

The adherence of CN Staph onto hydrophobic polymer surfaces may be due to hydrophobic interaction $[2,14]$. This means that $\mathrm{CN}$ Staph with a hydrophobic cell surface adhere to a higher extent onto such surfaces than strains with a hydrophilic cell surface. Recently, a linear correlation between cell surface hydrophobicity of CN Staph as determined by the xylene-water test and the bacterial adherence onto Teflon was reported $[15,17]$. However, Hogt et al. [10] demonstrated that cell surface hydrophobicity of $\mathrm{CN}$ Staph as determined by the xylene-water method was not predictive for the ability of the strains to adhere onto FEP. We demonstrated that non-encapsulated CN Staph strains adhered to a high extent onto FEP while the cell surface hydrophobicity as determined by the SAT also ranged widely. The range of SAT values of encapsulated and non-encapsulated strains was similar, but the adherence of most of the strains onto FEP was lower than that of the nonencapsulated strains. An explanation for the discrepancy between the cell surface hydrophobicity of $\mathrm{CN}$ Staph as measured and the adherence onto hydrophobic surfaces may be that the cell surface hydrophobicity is not the only factor involved $[10,17]$. Another explanation may be that the assays used to assess the cell surface hydrophobicity of $\mathrm{CN}$ Staph provide information about different cell surface properties.

Indeed, the data of our study reveal no correlation between the SAT value and the adherence of the 21 non-encapsulated and 14 encapsulated CN Staph strains to xylene. Similar findings were reported for various other bacterial species [22-24]. Several factors may explain the poor correlation between the SAT and the adherence to xylene. In the SAT the cell surface charge of the bacteria may interfere with the bacterial aggregation $[2,24]$. Bacteria with a rather high cell surface charge require a relatively high salt concentration to induce bacterial aggregation. It has been shown that CN Staph strains have a wide variation in their relative cell surface charge [11]. Therefore, the poor correlation between the results of the SAT and the xylene-water test when applied on the $\mathrm{CN}$ Staph strains may be due to the differences in the relative cell surface charge among the bacteria. The observation that encapsulated strains with low SAT values adhered in a low extent onto FEP may further illustrate the possible influence of the surface charge on the SAT value. Another factor to consider is that the xylene adherence test provides information about the ability of $\mathrm{CN}$ Staph to stabilize xylene-water emulsions [10]. Stabilization of these emulsions depends upon the molecular organization and the domain structure of hydrophobic and hydrophilic sites at the cell surface of the various test strains [10]. Non-encapsulated strains with low xylene-water method values adhered to a high extent onto FEP indicating that these strains have sufficient hydrophobic sites at their cell surface. Apparently, these strains, when applied in the xylene-water test, form water-xylene emulsions.

It has been suggested that a good agreement between the different assays to assess the cell surface hydrophobicity of bacteria is obtained if the tests are applied on a selection of strains which are quite similar in surface structure or surface composition [24]. Therefore, our findings show that the cell surface of various non-encapsulated and encapsulated $\mathrm{CN}$ Staph strains is rather heterogeneous. It may be that strains with a high degree of cell surface similarity have been used in a number of studies reporting a rather good linear correlation between the SAT value and the bacterial adherence to octane [26] or to octylsepharose $[19,27,28]$. 
In conclusion, values of the cell surface hydrophobicity of CN Staph obtained with the SAT and the xylene-water method do not correlate. Most likely, among CN Staph strains reorientation of bacterial cell surface structures occurs when the bacteria are exposed to the xylene--water system. On the other hand the cell surface charge of the bacteria may interfere with the SAT. Also, no correlation between the values of the SAT and the adherence of the bacteria onto FEP was observed.

\section{Acknowledgements}

We thank Bernadette Hüttenberger and Joy Steensma for the preparation of the typescript. This work was supported by a grant from The Netherlands Organization for the Advancement of Pure Research (ZWO).

\section{References}

1. G. D. CHRISTENSEN, Adv. Intern. Med. 32 (1987) 177.

2. J. DANKERT, A. H. HOGT and J. FEIJEN, in "CRC series in biocompatibility, vol. 2" (CRC Press Inc., Boca Raton, 1986) p. 219.

3. C. Watanakunakorn, Prog. Cardiovasc. Dis. 22 (1979) 181.

4. T. S. J. ELLiOTT, J. Med. Microbiol. 27 (1988) 161.

5. M. H. CHOO, D. R. HOLMES, B. J. GERSH. J. D. MALONEY, J. MEREDITH, J. R. PLUTH and J. TRUSTY, Amer. J. Cardiol. 48 (1981) 559.

6. G. D. CHRISTENSEN, W. A. SIMPSON, A. L. BISNO and E. H. BEACHY, Infect. Immun. 37 (1982) 318

7. S. U. DOUGHERTY and R. L. SIMMONS, Curr. Probl. Surg. 19 (1982) 218.

8. W. P. REED and R. C. WILLIA MS, J. Chron. Dis. 31 (1978) 67.

9 A. H. HOGT, J. DANKERT and J. FEIJEN, J. Gen. Microbiol. 131 (1985) 2485

10. A. H. HOGT, J. DANKERT, C. E. HULSTAERT and J. FEIJEN, Infect. Immun. 51 (1986) 294.
11. A. H. HOGT, J. DANKERT and J. FEIJEN, FEMS Microbiol. Lett. 18 (1983) 211.

12. Y. ICHIMAN and K. YOSHIDA, J. Appl. Microbiol. 51 (1981) 229.

13. J. J. YOUNGER, J. Infect. Dis. 156 (1987) 548.

14. A. H. HOGT, J. DANKERT and J. FEIJEN, J. Gen. Microbiol. 129 (1983) 2959.

15. A. FLEER, J. VERHOEF and A. P. HERNANDEZ, Amer. J. Med. 80 (suppl 6B) (1986) 161.

16. A. LUDWICKA, B. JANSEN, T. WADSTRÖM and $G$. PULVERER, Zentralbl. Bakteriol. Mikrobiol. Hyg. Ser. A 256 (1984) 479.

17. A. PASCUAL, A. FLEER, N. A. C. WESTERDAAL and J. VERHOEF, Eur. J. Microbiol. 5 (1986) 518.

18. M. ROSENBERG, D. GUTNICK and E. ROSENBERG, FEMS Microbiol. Lett. 9 (1980) 29.

19. M. LINDAHL, A. FARIS, T. WADSTRÖM and S. HJERTÉN, Biochim. Biophys. Acta 677 (1981) 471.

20. C. J. SMYTH, P. JONSSON, E. OLSSON, O. SÖDERLIND, J. ROSENGREN, S. HJERTEN and T. WADST RÖM, Infect. Immun. 22 (1978) 462.

21. H. J. BUSSCHER, A. H. WEERKAMP, H. C. VAN DER MEI, A. W. J. VAN PELT, H. P. DE JONG and J. ARENDS, Appl. Environ. Microbiol. 48 (1984) 980.

22. J. K. DILLON, J. A. FUERST, A, C. HAYWARD and G. H. G. DAVIS, J. Microbiol. Methods 6 (1986) 13.

23. N. MOZES and P. G. ROUXHET, J. Microbiol. Methods 6 (1987) 99.

24. H. C. VAN DER MEI, A. H. WEERKAMP and H. J. BUSSCHER, J. Microbiol. Methods 6 (1987) 277.

25. J. P. DUGUID, J. Pathol. Bacteriol. 63 (1951) 673.

26. N. D. PAR KER and C. B. MUNN, FEMS Microbiol. Lett. 21 (1984) 233.

27. W. B. CLARK, M. D. LANE, E. BEEM, S. L. BRAGG and T. T. WHEELER, Infect. Immun. 47 (1985) 730.

28. A. FARIS, M. LINDAHL and T. WADSTRÖM, Curr. Microbiol. 7 (1982) 357.

Received 7 September 1990

and accepted 7 January 1991 